\title{
Controlling Digital Dermatitis: Copper Sodium Hypochlorite Versus Copper Sulfate Footbath
}

\author{
Barbara Jonesa $\mathbf{W}^{1 *}$, Joey Clarkb D ${ }^{1}$, Jeffrey Bewleye $\mathbf{M}^{1}$, Kristen McQuerryc J2 , and Sarah Jansed W2 \\ ${ }^{1}$ Department of Animal and Food Sciences, University of Kentucky, USA \\ ${ }^{2}$ Department of Statistics, University of Kentucky, USA
}

Submission: May 05, 2017; Published: July 21, 2017

*Corresponding author: Barbara Jones, Department of Animal and Food Sciences, University of Kentucky, Lexington, USA, Tel: 207-749-2766;

Email: barbara.wadsworth@uky.edu

\begin{abstract}
The objective of this study was to compare the odds of having a digital dermatitis (DD) lesion between a copper sodium hypochlorite solution (treatment; $2.5 \%$ copper sulfate footbath with $1.4 \mathrm{~L}$ of sodium hypochlorite solution added) and $5 \%$ copper sulfate footbath (positive control). Holstein cows $(\mathrm{n}=66)$ were housed in two free stall barns ( $A$ and B). Footbath solutions were administered through two polyethylene footbaths. Cows in barn A passed through the positive control ten times per week and the solution was refreshed every other day. Cows in barn B passed through the treatment ten times per week and the solution was refreshed every day. Left and right rear hoof DD lesions were scored weekly for active or non-active DD lesions. The GENMOD procedure of SAS was used to analyze the odds of having an active lesion with each footbath solution for each hoof. The odds ratio of having an active lesion was 2.66 times greater ( $\mathrm{P}=0.08 ; 95 \% \mathrm{CI}=0.86$ to 8.17 ) for the treatment compared to the positive control for the left rear hoof. The odds ratio of having an active lesion was 0.92 times lesser $(\mathrm{P}=0.89$; $95 \% \mathrm{CI}=0.30$ to 2.91 ) for the treatment compared to the positive control for the right rear hoof. No differences were observed for active digital dermatitis lesions between the positive control and treatment footbath solutions.
\end{abstract}

Keywords: Digital dermatitis; Footbath; Copper sulfate

Abbreviations: DD: Digital Dermatitis; CS: Copper Sulfate

\section{Introduction}

Digital dermatitis (DD) is a relatively new disease, first described in 1974 in Italy [1]. Digital dermatitis is a painful disease caused by a bacterial infection that leads to inflammation and skin damage that mainly affects the heel skin of cattle [2] and is a main cause of lameness [3]. However, the infection is hard to control because DD is poly microbial. The bacteria identified are typically Spirochetes of the genus Treponema [4-6]. Though the main cause has been identified, determining mode of DD transmission has proven difficult to determine. Studies have pinpointed treponemes in the dairy cow environment [7], in the oral and rectal tissues of cattle [8] and in the rumen and feces of cattle.

Somers [9] reported that cow-level prevalence of DD was $27.3 \%$ for cows that were housed on pasture and $28.5 \%$ for cows housed in confinement showing high prevalence rates for DD on farms overall [10] reported that cow DD prevalence was $33 \%$ [11] revealed that DD prevalence was $21.2 \%$. The national animal health monitoring system also found high prevalence rates in cows with $49.1 \%$ of all lame cases being caused by DD [12].

On-farm prevention is key to controlling DD. Footbaths are a common practice to prevent DD. The NAHMS stated that $20 \%$ of all operations used footbaths year round. Common footbath solutions are copper sulfate (CS) or formalin solutions [13]. Copper sulfate and formalin were used on $66.6 \%$ and $10.9 \%$ of operations that used footbaths, respectively [14]. Whereas these footbath solutions are useful in prevention, the solutions may be detrimental to the environment or human health [15]. Copper sulfate has detrimental environmental effects when the footbath waste is disposed of into manure handling systems [16]. Best estimates elude that copper is being applied to fields at a rate of 45 to 50 times above the needed amount. Copper overload in fields could be poisonous to plants and microbes in the soil and can reduce plant productivity. Formalin is a known carcinogen [17]. Studies evaluating alternative footbath solutions besides CS and formalin are needed. Finding new footbath solutions that do not include CS is the best long-term goal. 
Smith reported that a $3 \%$ tea tree oil foot bath solution was an effective means to prevent DD compared to a 5\% CS footbath solution. Teixeira reported that Dragonhyde solution was also an effective means to prevent DD compared to a $10 \%$ CS footbath solution and Laven \& Hunt [18] found that peracetic acid solution also prevented DD at the same rate as a 5\% CS. These different studies emphasizes that other footbath solutions can be as effective as CS. However, literature surrounding footbath solutions is scarce. A copper sodium hypochlorite solution could potentially reduce the amount of CS used in a footbath solution while still sanitizing the hooves simultaneously. Therefore, the objective of this study was to compare a copper sodium hypochlorite footbath solution to a 5\% CS footbath solution on preventing the frequency and severity of DD.

\section{Materials and Methods}

This study was approved through the University of Kentucky Institutional Animal Care and Use Committee (IACUC protocol number: 2013-1143) and was conducted at the University of Kentucky Cold stream Research dairy farm from May 11, 2015 to June 26,2015 . Holstein dairy cows $(n=66)$ were housed in two free stall barns and cows were randomly assigned to the free stall barns and were balanced for parity and days in milk. One barn was equipped with sawdust covered Dual Chamber Cow Waterbeds (Advanced Comfort Technology, Reedsburg, WI; barn A) and another with sawdust covered rubber-filled mattresses (Promat Inc., Woodstock, Ontario, Canada; barn B). Each barn received different footbath solutions. One footbath solution was a copper sodium hypochlorite footbath (treatment; $2.5 \% \mathrm{CS}$ footbath with $1.4 \mathrm{~L}$ of sodium hypochlorite solution added at a $12 \%$ concentration) and the other solution was a $5 \%$ CS footbath (positive control). Footbath solutions were administered through two polyethylene footbaths (J\&D Manufacturing, Eau Claire, Wisconsin) in separate locations.

Each foot bath measured $15.24 \mathrm{~cm} \times 81.28 \mathrm{~cm} \times 198.12 \mathrm{~cm}$ and held 94.64L of footbath solution. Cows in barn A passed through the positive control footbath five days a week, two times per day, and the footbath solution was discarded and refreshed every other day (which allowed for up to 200 cow passes). Cows in barn B passed through the treatment footbath five days a week, two times per day, and the footbath solution was discarded and refreshed every day (which allowed for up to 100 cow passes). The treatment footbath solution was changed daily because the reaction time of the treatment solution was lesser than positive control solution. Both barns received the same free stall cleaning, the same stall sawdust application, and same alley floor scraping once daily. Before the study, cows walked through a $5 \%$ CS preventative maintenance bath weekly and hoof trimming occurred on March 13, 2015.

Left and right rear hoof DD lesions were scored weekly in the parlor by the same observer. For logistical reasons, the scorer was not blinded to which cows received the treatment or positive control foot baths. A headlamp was used to ensure sufficient lighting was available and hooves were washed before scoring to ensure accurate scoring. Stokes [19] determined that scoring hooves for DD in the parlor was a reliable method of scoring. A M0 to M4 scoring system was employed: M0 indicated no lesion; M1 represented an early growth $<2 \mathrm{~cm}$ in size; M2 indicated an ulcerative lesion $>2 \mathrm{~cm}$ in size; $\mathrm{M} 3$ represented a healing growth; and M4 indicated a chronic growth [20]. The DD lesions were further separated into active lesions (M1 and M2) or non-active lesions (M0, M3, and M4) for statistical analysis.

For the analysis, cows that were not on the study for the entirety were deleted. Eighty-nine cows were scored through the study and reasons for removal were drying off, culling, freshening after the study started, and being placed on other research projects. The GENMOD procedure of SAS (SAS Institute, Inc., Cary, NC) was used to analyze the odds ratio of having an active lesion with each treatment on both left and rear hooves. A chi-square analysis was performed using the FREQ procedure to compare prevalence rates of all DD lesions across the study for each footbath solution for each hoof. A chi-square analysis was performed using the FREQ procedure to evaluate prevalence rates of DD lesions between the left and right rear hooves.

\section{Results}

Table 1: Active digital dermatitis lesions frequencies for each week of the study and treatment group ${ }^{1,2}$

\begin{tabular}{|c|c|c|c|}
\hline Week & Hoof & $\begin{array}{c}\text { Treatment }^{3} \\
\text { (No (\%) of Hooves } \\
\text { with Digital } \\
\text { Dermatitis) }\end{array}$ & $\begin{array}{c}\text { Positive Control }^{4} \\
\text { (No (\%) of Hooves } \\
\text { with Digital } \\
\text { Dermatitis) }\end{array}$ \\
\hline 1 & Left & $2(7.41)$ & $3(11.11)$ \\
\hline 2 & Right & $4(6.45)$ & $6(9.68)$ \\
\hline & Left & $4(14.81)$ & $1(3.70)$ \\
\hline 3 & Right & $5(8.06)$ & $6(9.68)$ \\
\hline & Left & $1(3.70)$ & $1(3.70)$ \\
\hline 4 & Right & $5(8.06)$ & $5(8.06)$ \\
\hline & Left & $4(14.81)$ & $0(0)$ \\
\hline 5 & Right & $3(4.84)$ & $3(4.84)$ \\
\hline & Left & $4(14.81)$ & $1(3.70)$ \\
\hline 6 & Right & $4(6.45)$ & $4(6.45)$ \\
\hline & Left & $1(3.70)$ & $0(0)$ \\
\hline 7 & Right & $4(6.45)$ & $5(8.06)$ \\
\hline & Left & $3(11.11)$ & $2(7.41)$ \\
\hline
\end{tabular}

1. Hooves were scored weekly for the duration of the study by the same observer.

2. Left and right rear hoof digital dermatitis lesions were scored weekly in the parlor using a M0 to M4 scoring system: M0 indicated no lesion; M1 represented an early growth $<2 \mathrm{~cm}$ in size; M2 indicated an ulcerative lesion $>2 \mathrm{~cm}$ in size; $\mathrm{M} 3$ represented a healing growth; and M4 designated a chronic growth [20]. The digital dermatitis lesions were further separated into active lesions (M1 and M2) or non-active lesions (M0, M3, and M4).

3. Treatment footbath solution $=2.5 \%$ copper sulfate footbath with $1.4 \mathrm{~L}$ of sodium hypochlorite solution added). 
4. Positive control=5\% copper sulfate footbath

Active DD scores for each week, each hoof, and footbath solution are shown in (Table 1). A chi-square test performed indicated that no active lesion differences were observed between the two footbath solutions for the left hooves $(\mathrm{P}=0.49$; $\chi 2$ value $=5.42)$ and for the right hooves $(P=0.99 ; \chi 2$ value $=0.35)$. Active and non-active DD scores for each footbath solution are shown in (Table 2). No difference in active lesions were observed between treatment and control groups for the left rear hoof $(\mathrm{P}=0.08)$ and for the right rear hoof $(\mathrm{P}=0.89)$. The odds ratio of having an active lesion was 2.66 times greater $(\mathrm{P}=0.08$; $95 \%$ $\mathrm{CI}=0.86$ to 8.17 ) for the treatment compared to the positive control for the left rear hoof. The odds ratio of having an active lesion was 0.92 times lesser $(\mathrm{P}=0.89 ; 95 \% \mathrm{CI}=0.30$ to 2.91 ) for the treatment compared to the positive control for the right rear hoof. A chi-square test performed indicated that no differences were observed between left and right hooves $\left(\mathrm{P}=0.83 ; \chi^{2}\right.$ value=2.77).

Table 2: Active and non-active digital dermatitis lesion frequencies and treatment group1, 2.

\begin{tabular}{|c|c|c|c|}
\hline \multirow{2}{*}{$\begin{array}{c}\text { Digital } \\
\text { Dermatitis }\end{array}$} & Hoof & $\begin{array}{c}\text { Treatment3 } \\
\text { (No. (\%) } \\
\text { of Hooves } \\
\text { with Digital } \\
\text { Dermatitis) }\end{array}$ & $\begin{array}{c}\text { Positive Control4 } \\
\text { [No. (\%) of Hooves } \\
\text { with Digital } \\
\text { Dermatitis] }\end{array}$ \\
\hline Non-active & Left & $205(47.13)$ & $230(52.87)$ \\
\hline & Right & $195(48.75)$ & $205(51.25)$ \\
\hline Active & Left & $19(70.37)$ & $8(29.63)$ \\
\hline & Right & $29(46.77)$ & $33(53.23)$ \\
\hline
\end{tabular}

1. Hooves were scored weekly for the duration of the study by the same observer.

2. Left and right rear hoof digital dermatitis lesions were scored weekly in the parlor using a M0 to M4 scoring system: M0 indicated no lesion; M1 represented an early growth $<2 \mathrm{~cm}$ in size; $M 2$ indicated an ulcerative lesion $>2 \mathrm{~cm}$ in size; $\mathrm{M} 3$ represented a healing growth and M4 designated a chronic growth [20]. The digital dermatitis lesions were further separated into active lesions (M1 and M2) or non-active lesions (M0, M3, and M4).

3. Treatment footbath solution $=2.5 \%$ copper sulfate footbath with $1.4 \mathrm{~L}$ of sodium hypochlorite solution added).

4. Positive control=5\% copper sulfate footbath.

\section{Discussion}

Overall, no differences were observed between the two footbath solutions. The treatment footbath solution was a viable option as a footbath solution. Copper sulfate waste that is applied to fields could be environmentally detrimental. Therefore, finding alternatives to CS is important. The treatment solution reduces the use of $\mathrm{CS}$ in the footbath solution. Using this solution in the footbath could potentially reduce the amount of CS waste applied to fields.

Neither footbath solutions showed a DD improvement over the seven-week study. Whereas this may be concerning, the percentage of DD in the study (0 to $14.81 \%$ ) was lesser compared to other studies ( 21.2 to $33 \%$ ). Footbaths are meant to be a preventative measure rather than a cure for DD. Therefore, not reducing DD frequency from beginning to end of the present study is not surprising. Rather the effectiveness is shown in the footbaths ability to prevent new DD infections.

Although numerical differences were shown between the left and right hind hooves, no statistical differences were observed [21] also reported no significant differences between the left and right hind hooves concerning DD presence [22] showed numerical differences between the right and left rear hoof, but no statistical analysis was performed in this study to show statistical differences.

The present study did not reduce the CS level used in the treatment footbath as it needed to be refreshed daily. This frequent changing compared to the positive control resulted in the same amount of CS used in both footbath solutions. However, no differences were observed between the two foot bath solutions. Future studies where the treatment solution efficacy could be evaluated by changing the bath less frequently should be conducted. While these results are promising toward reducing CS waste, power may have been an issue. Future studies where power is not an issue should be conducted.

\section{Conclusion}

In this study, no differences were observed for active digital dermatitis lesions between the control and treatment footbath solutions. The treatment footbath solution is a viable option for a footbath solution. Although these results are promising, the authors caution that power may have been an issue in the current study.

\section{Acknowledgement}

We wish to thank GEA Farm Technologies for their support of the study. We also wish to thank Taylor Reiter for her technical support during the study. We would also like to thank the Cold stream Dairy farm staff for their continuous dedication to the project. We also wish to thank Brandon Beavers for his help with the project.

\section{References}

1. Cheli R, Mortellaro C (1974) Digital Dermatitis in Cattle, in $8^{\text {th }}$ International Conference on Diseases of Cattle. Milan, Italy, pp. 208213.

2. Laven RA, Proven MJ (2000) Use of an antibiotic foot bath in the treatment of bovine digital dermatitis. Vet Rec 147(18): 503-506.

3. Laven RA, Logue DN (2006) Treatment strategies for digital dermatitis for the UK. Vet J171(1): 79-88.

4. Evans NJ, Brown JM, Demirkan I, Murray RD, Vink WD, et al. (2008) Three unique groups of spirochetes isolated from digital dermatitis lesions in UK cattle. Vet Microbiol 130(1-2): 141-150.

5. Walker RL, Read DH, Loretz KJ, Nordhausen RW (1995) Spirochetes isolated from dairy cattle with papillomatous digital dermatitis and interdigital dermatitis. Vet Microbiol 47(3-4): 343-355.

6. Zinicola M, Lima F, Lima S, Machado V, Gomez M, et al. (2015) Altered 
Microbiomes in Bovine Digital Dermatitis Lesions, and the Gut as a Pathogen Reservoir. PLoS ONE 10(3): e0120504.

7. Klitgaard K, Nielsen MW, Ingerslev HC, Boye M, Jensen TK (2014) Discovery of Bovine Digital Dermatitis-Associated Treponema spp. in the Dairy Herd Environment by a Targeted Deep-Sequencing Approach. Appl and Environ Microbiol 80(14): 4427-4432.

8. Evans NJ, Timofte D, Isherwood DR, Brown JM, Williams JM, et al (2012) Host and environmental reservoirs of infection for bovine digital dermatitis treponemes. Vet Microbiol 156(1-2): 102-109.

9. Somers JG, Frankena K, Noordhuizen-Stassen EN, Metz JH (2005) Risk factors for digital dermatitis in dairy cows kept in cubicle houses in The Netherlands. Prev Vet Med 71(1-2): 11-21.

10. Argaez-Rodriguez FJ, Hird DW, Hernández de Anda J, Read DH, Rodríguez-Lainz A (1997) Papillomatous digital dermatitis on a commercial dairy farm in Mexicali, Mexico: incidence and effect on reproduction and milk production. Prev Vet Med 32(3-4): 275-286.

11. Holzhauer M, Hardenberg C, Bartels CJ, Frankena K (2006) Herd- and Cow-Level Prevalence of Digital Dermatitis in The Netherlands and Associated Risk Factors. J dairy science 89(2): 580-588.

12. NAHMS (2007) Part V: Changes in Dairy Cattle Health and Management Practices in the United States, 1996-2007. USDA, APHIS, VS, CEAH National Animal Health Monitoring Systems. Fort Collins, USA, pp. $1-100$.

13. Teixeira AG, Machado VS, Caixeta LS, Pereira RV, Bicalho RC (2010) Efficacy of formalin, copper sulfate, and a commercial footbath product in the control of digital dermatitis. J Dairy Sci 93(8): 3628-3634.

14. NAHMS (2007) Part IV: Reference of Dairy Cattle Health and
Management Practices in the United States, 2007. USDA, APHIS, VS, CEAH, National Animal Health Monitoring Systems. Fort Collins, USA, pp. 1-185.

15. Manske T, Hultgren J, Bergsten C (2002) Topical treatment of digital dermatitis associated with severe heel-horn erosion in a Swedish dairy herd. Preventive Veterinary Medicine 53(3): 215-231.

16. Downing TW, Stiglbauer K, Gamroth MJ, Hart J (2010) CASE STUDY: Use of Copper Sulfate and Zinc Sulfate in Footbaths on Oregon Dairies. Professional. Animal Scientist 26: 332-334.

17. Smith AC, Wood CL, McQuerry KJ, Bewley JM (2014) Effect of a tea tree oil and organic acid footbath solution on digital dermatitis in dairy cows. J Dairy Sci 97(4): 2498-2501.

18. Laven RA, Hunt H (2002) Evaluation of copper sulphate, formalin and peracetic acid in footbaths for the treatment of digital dermatitis in cattle. Vet Rec 151(5): 144-146.

19. Stokes JE, Leach KA, Main DC, Whay HR (2012) The reliability of detecting digital dermatitis in the milking parlour. Vet J 193: 679-684.

20. Dopfer D, ter Huurne AAHM, Cornelisse JL, van Asten AJAM, Koopmans $A$, et al. (1997) Histological and bacteriological evaluation of digital dermatitis in cattle, with special reference to spirochaetes and Campylobacter faecalis. Veterinary Record 140(24): 620-623.

21. Laven R (1999) The environment and digital dermatitis. Cattle Practice 7: $349-354$

22. Yeruham I, Perl S (1998) Clinical aspects of an outbreak of papillomatous digital dermatitis in a dairy cattle herd : case report. Journal of the South African Veterinary Association 69(3): 112-115

\section{Your next submission with Juniper Publishers} will reach you the below assets

- Quality Editorial service

- Swift Peer Review

- Reprints availability

- E-prints Service

- Manuscript Podcast for convenient understanding

- Global attainment for your research

- Manuscript accessibility in different formats

( Pdf, E-pub, Full Text, Audio)

- Unceasing customer service

Track the below URL for one-step submission https://juniperpublishers.com/online-submission.php 